\title{
Nutrient removal from activated sludge mixed liquor by wastewater protozoa in a laboratory scale batch reactor
}

\author{
O. B. Akpor; * M. N. B. Momba; J. O. Okonkwo; M. A. Coetzee \\ Department of Environmental, Water and Earth Sciences, Tshwane University of Technology, Pretoria, \\ P/Bag X680, Pretoria, 0001, South Africa
}

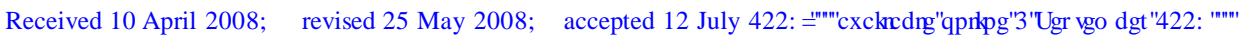

\begin{abstract}
The aim of the study was to investigate the nutrient removal rate of three wastewater protozoan isolates (Aspidisca, Trachelophyllum and Peranema). The study was carried out in a laboratory-scale batch reactor for a period of $120 \mathrm{~h}$. in a four batch study. Aliquot samples were withdrawn from the reactor every $24 \mathrm{~h}$. for the analysis of phosphate, nitrate, nitrite, ammonia, chemical oxygen demand, dissolved oxygen and $\mathrm{pH}$, using standard methods. The results obtained in the different batches among the three isolates showed $\mathrm{PO}_{4}{ }^{2-}$ removal rate ranging from 0.04 to 0.52 mg- $\mathrm{PO}_{4}{ }^{2-} / \mathrm{L} / \mathrm{h}$. while $\mathrm{NO}_{3}^{-}$nitrate removal rates ranged from 0.08 to $0.16 \mathrm{mg}-\mathrm{NO}_{3}^{-} / \mathrm{L} / \mathrm{h}$. Also $\mathrm{NO}_{2}^{-}$and $\mathrm{NH}_{3}$ rates were observed to range between 0.022 and $0.087 \mathrm{mg}-\mathrm{NO}_{2}-\mathrm{L} / \mathrm{h} .0 .05$ and $0.16 \mathrm{mg}^{-\mathrm{NH}_{3}}-\mathrm{L} / \mathrm{h}$, respectively. For the physicochemical parameters, there was no observed COD decrease; rather there was an increase and this was irrespective of isolates and experimental batches. However, dissolved oxygen concentration decreased drastically (below $1 \mathrm{mg} / \mathrm{L}$ ) at the end of each batch while $\mathrm{pH}$ show a decrease after an initial $24 \mathrm{~h}$. period and thereafter increased. This trend was also irrespective of isolates and experimental batches. Overall, the study has been able to show the effect of the test isolates on nutrient removal rates and other physicochemical parameters (COD, $\mathrm{DO}$ and $\mathrm{pH}$ ) in activated sludge mixed liquor.
\end{abstract}

Key words: Phosphate, nitrite, nitrate, ammonia, chemical oxygen demand, dissolved oxygen

\section{INTRODUCTION}

Nutrients in wastewater such as phosphates and nitrogen compounds stimulate the growth of algae and other photosynthetic aquatic life, which lead to accelerated eutrophication of lakes and other natural waters (Kortstee et al., 2000). Apart from stimulating the growth of algae, eutrophication also causes increased water purification cost, interference with the recreational value of water, health risks to humans and livestock, excessive loss of oxygen and undesirable changes in aquatic populations (Kuba et al., 1997). Biological nutrient removal from domestic and industrial wastewaters is a key factor in preventing eutrophication and is one of the most economical and efficient methods for nutrient removal (Behera et al., 2007). The activated sludge process is the most widely applied biological wastewater treatment process (Sidat et al., 1999; Doorn et al., 2006; Okoh et al., 2007). The importance of protozoa in wastewater treatment involving activated sludge has been described in the past (Salvado et al., 1995; Ratsak et al., 1996; Dola, 1997). Apart from the effectiveness of protozoa in

\footnotetext{
*Corresponding Author Email: mombamnb@tut.ac.za

Tel: +27012382 6365, Fax +270123826233
}

wastewater purifying process, due to their ability to feed on dispersed bacteria, (thus eliminating them), they are known to excrete mineral nutrients, including nitrogen and phosphorus.

This process helps to recycle nutrients in the activated sludge (Gerardi, 2007). The participation of protozoa in the cycling of carbon and nutrients (phosphorus and nitrogen) in aquatic systems and activated sludge mixed liquor and to a lesser extent in the soil has been studied in some detail (Taylor, 1982; Zwart et al., 1994; Johanna et al., 1999).

Most of the previous studies that dealt with the investigation of protozoa in nutrient removal from activated sludge mixed liquor have been carried out in shake flasks conditions (Salvado, 2001; Akpor et al., 2007 and 2008). In shaking flask conditions, experiments are run for a few days with a small volume of mixed liquor. There is little information on the roles and activities of protozoa in nutrient removal in laboratory-scale reactors, which are operated at longer times with a larger volume of mixed liquor.

This study was therefore aimed at investigating the nutrient (phosphate, nitrate, ammonia and nitrite) 
removal rate of three wastewater protozoan isolates in activated sludge mixed liquor in laboratory-scale reactors; operated in batches. The effects of the isolates on other physicochemical factors, such as chemical oxygen demand (COD), dissolved oxygen (DO) and $\mathrm{pH}$ values were also investigated

\section{MATERIALS AND METHODS}

Test organisms

Three test protozoan isolates were used for this investigation. The isolates (Aspidisca, Trachelophyllum and Peranema) have previously been ascertained to have nutrient removal ability under shake flask conditions (Akpor et al., 2007). They were isolated from the aerobic zone of Daasport Wastewater Treatment Plant, Pretoria, South Africa in October 2006. The present study was carried out between October 2007 and February 2008.

\section{Experimental set up}

Two laboratory-scale batch reactors (one inoculated and a control), each made of perspex glass with $55 \mathrm{~cm}$ height and $22 \mathrm{~cm}$ diameter were used for the study. The schematic representation of the set up is shown in Fig. 1. Each reactor had a working volume capacity of 20 L. Prior to use, each reactor was sterilized, using $5 \%$ sodium hypochlorite for $24 \mathrm{~h}$., after which it was rinsed with sterile sodium thiosulphate solution before adding sterile mixed liquor. For each isolate, the reactors (inoculated and control) were operated for four batches, with each batch running for $120 \mathrm{~h}$.

At the expiration of each batch, the system was allowed to settle, after which the mixed liquor was sucked out, using suction with pumps previously sterilized, as described above before fresh mixed liquor was added to the reactor to start a new batch. The contents of the reactors were kept in suspension by means of stirrers (50 rpm) that were powered by an electric motor attached to the reactor. Air was supplied to the reactors by means of oxygen diffusers that have previously been sterilized, as described above. All reagents used were of analytical grade.

\section{Operating conditions}

Wastewater used for this investigation was collected from the anaerobic zone of Daasport Wastewater Treatment Plant in Pretoria, South Africa. The wastewater (referred to as mixed liquor) was allowed to settle, after which it was filtered, using Whatman No. 1 filter paper. After filtration, the following salts were added: sodium acetate (to serve as carbon source), magnesium sulphate, potassium nitrate, sodium nitrite, and ammonium chloride, at concentrations of $5 \mathrm{~g} / \mathrm{L}, 0.5$ $\mathrm{g} / \mathrm{L}, 0.18 \mathrm{~g} / \mathrm{L}, 0.1 \mathrm{~g} / \mathrm{L}$ and $0.1 \mathrm{~g} / \mathrm{L}$, respectively. The mixed liquor was sterilized, using an autoclave and a $10 \mathrm{~L}$ quantity was then transferred to each reactor, before inoculating with a rich culture of a single isolate. The same procedure was repeated (for other isolates). The control was left uninoculated at each stage. For each isolate, the batch reactor for operated for four batches with aeration and agitation for $120 \mathrm{~h}$., per batch.

\section{Analysis}

At time zero and every $24 \mathrm{~h}$., for the next $120 \mathrm{~h}$. (for each batch), aliquot sample $(100 \mathrm{~mL})$ was collected aseptically from each reactor (by means of a sterile pump), for the estimation of total phosphate, nitratenitrogen, nitrite-nitrogen, total ammonia, COD, using the ascorbic acid, salicylate, spectrophotometric, titrimetric and closed reflux methods, respectively, as described in standards methods (APHA, 2001). Other parameters, such as $\mathrm{pH}$ and DO were analyzed using a $\mathrm{pH}$ meter and an electric dissolved oxygen probe, respectively. Nutrient removal and increase rates were determined using the equation below:

$$
\frac{\left[C_{1}-C_{2}\right]}{120 \times h}
$$

Where $\mathrm{C}_{1}=$ Initial concentration $(\mathrm{mg} / \mathrm{L})$

$\mathrm{C}_{2}=$ Final concentration $(\mathrm{mg} / \mathrm{L})$

\section{RESULTS AND DISCUSSION}

As shown in Fig. 2, phosphate removal rate among the different isolates in the different batches reveal removal rate that ranged from 0.34 to $0.52 \mathrm{mg}-\mathrm{PO}_{4} / \mathrm{L} / \mathrm{h}$., 0.17 to $0.49 \mathrm{mg}-\mathrm{PO}_{4} / \mathrm{L} / \mathrm{h}$. and 0.04 to $0.48 \mathrm{mg}-\mathrm{PO}_{4} / \mathrm{L} / \mathrm{h}$. in mixed liquor inoculated with Aspidisca, Trachelophyllum and Peranema, respectively. Apart from the case of Aspidisca, remarkable removal rates were observed in all the batches, while lower values of removal rates were observed in batches three and four for mixedliquor inoculated with either Trachelophyllum or Peranema.On the other hand, as can be seen in Fig. 3, nitrate removal rates were observed to range from 0.14 to $0.16 \mathrm{mg}-\mathrm{NO}_{3} / \mathrm{L} / \mathrm{h}$. for Aspidisca, 0.09 to $0.12 \mathrm{mg}-\mathrm{NO}_{3} / \mathrm{L} / \mathrm{h}$. for Trachelophyllum and 0.08 to 0.11 mg- $\mathrm{NO}_{3} / \mathrm{L} / \mathrm{h}$. for Peranema. Lowest values of nitrate 


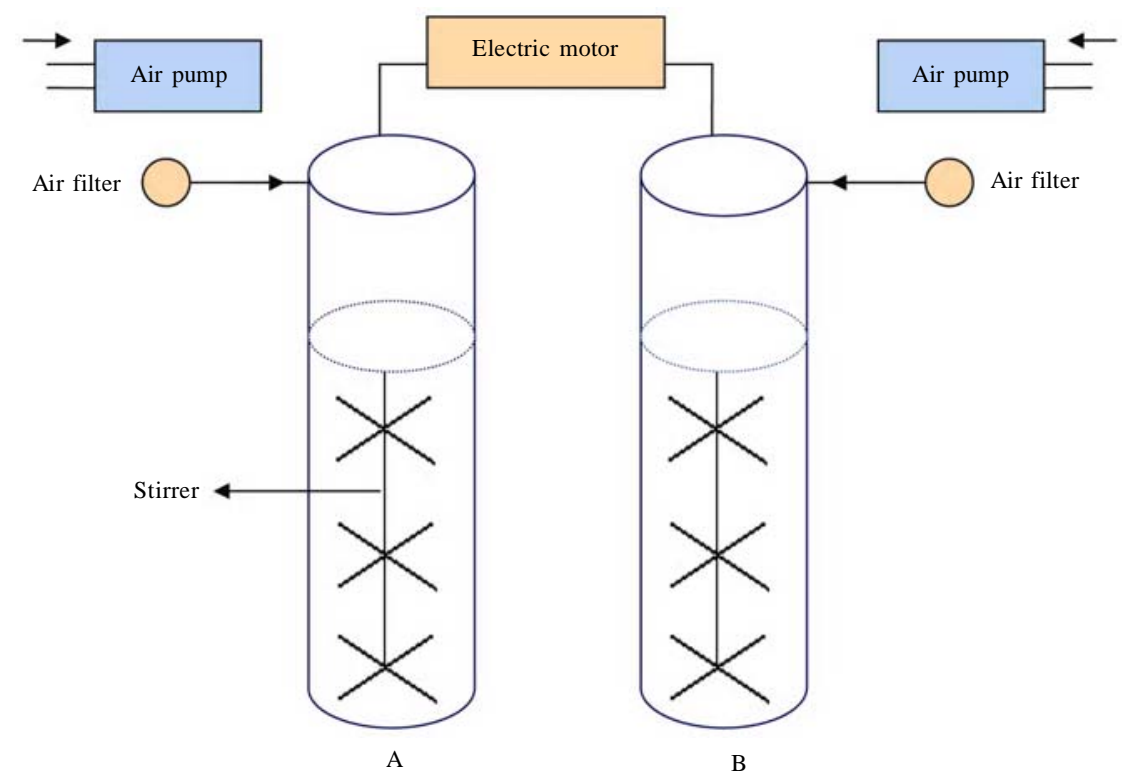

Fig. 1: Schematic diagram of the batch reactors used for the study. A and B represent the inoculated and the uninoculated reactors

removal rates were observed in batch three for both Trachelophyllum and Peranema.

As was observed in phosphate removal rate, remarkable nitrate removal was observed in all the batches when Aspidisca was used as the inoculum.

All the isolates used in this study have been ascertained to have nitrate and phosphate removal ability in our previous investigation (Akpor et al., 2008). The mixed liquor used was supplemented with sodium acetate, to serve as a source of carbon for the isolates.

The choice of sodium acetate was deliberate since it has been shown by previous investigators to be a preferred carbon source for nutrient removal from wastewater by microorganisms (Sang et al., 1997; Kargi and Uygur, 2003). Another reason for the choice of acetate was because nutrient removal process in activated sludge is known to depend on the availability of easily biodegradable carbon sources. Although the amount of biodegradable carbon compounds cannot be measured directly, various authors have proposed different concentrations of readily biodegradable carbon source in wastewater that could enhance nutrient removal (Ekama et al., 1986; Morales et al., 1991). This study has revealed varying nutrient removal rates in the different experimental batches in the reactors, among the different isolates. Phosphate removal and release have been reported to occur in fully aerobic conditions in sequencing batch reactors if the aeration is prolonged. This may probably be due to the depletion of carbon store in the cells, thus resulting in the degradation of polyphosphate, which can result in the beginning of a new carbon store build up (Matuzevicius and Valentukeciene, 2007).

Simultaneous phosphate and nitrate removals were observed in this investigation. Reports have shown that complete denitrification is essential for phosphate removal (Rybicki, 1997; Sang et al., 1997). Other studies have shown that the schemes for nitrogen and phosphorus removal have been reported to be closely linked, both in positive and negative sense (Morales et al., 1991). Simultaneous nitrate and phosphate removals in similar investigation have been reported also by Lee et al.,(2001). Although this was not investigated in this study, nitrates are considered to have adverse effect on phosphorus removing capacity of activated sludge. Biological nitrogen removal from wastewater is also reported to be based on the nitrification and denitrification process (Matuzevicius and Valentukeciene, 2007).

The low phosphate removal rate observed in the later batches in two of the isolates could be attributed to a probable low cell synthesis in such batches. Moosavi et al. (2005) have attributed phosphorus removal to cell synthesis, hence suggested that 


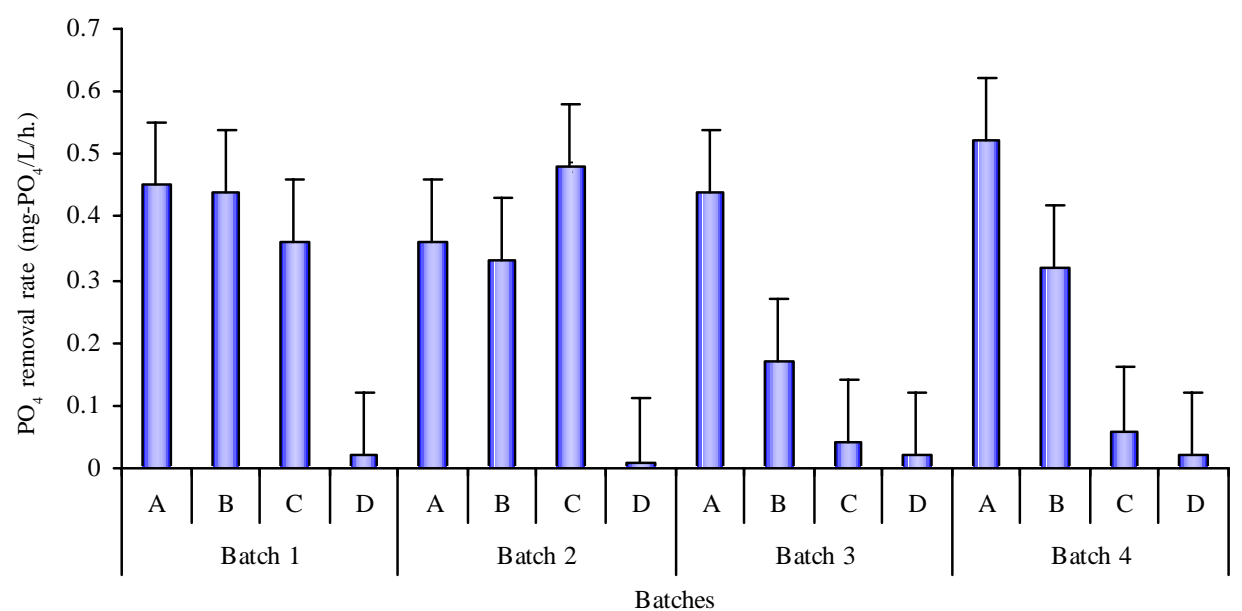

Fig. 2: Variation of phosphate removal rate from mixed liquor inoculated with different isolates from different batches $(\mathrm{A}=$ Aspidisca, $\mathrm{B}=$ Trachelophyllum, $\mathrm{C}=$ Peranema, $\mathrm{D}=$ uninoculated control $)$

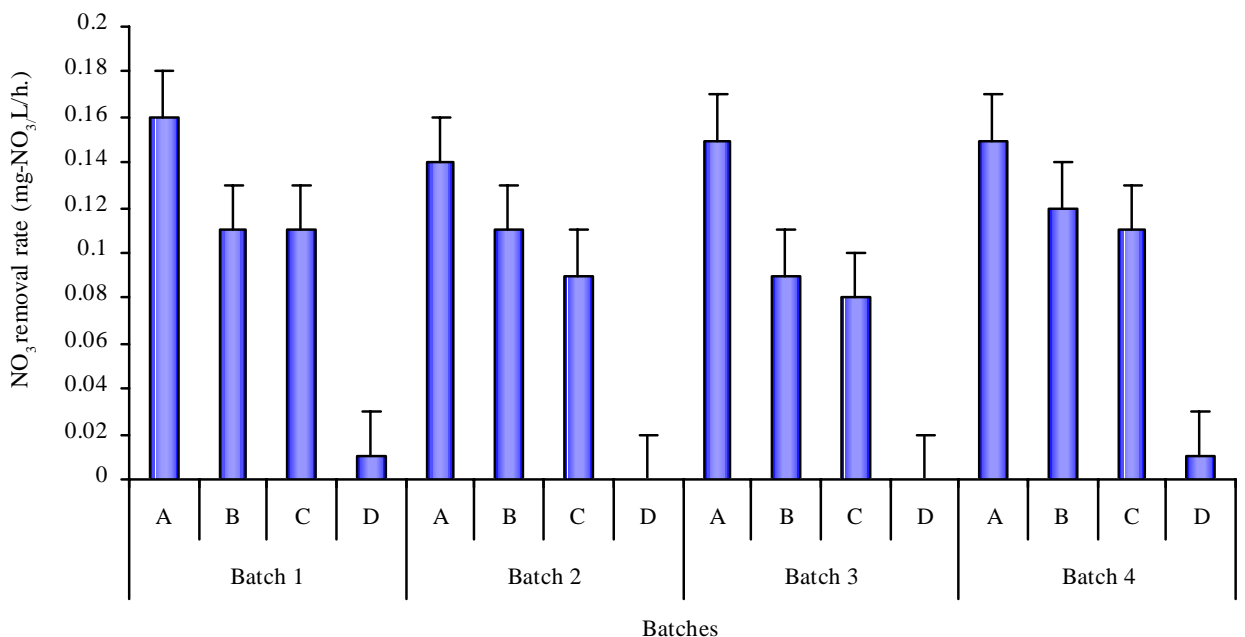

Fig. 3: Variation of nitrate removal rate from mixed liquor inoculated with different isolates from different batches (A= Aspidisca, $\mathrm{B}=$ Trachelophyllum, $\mathrm{C}=$ Peranema, $\mathrm{D}=$ uninoculated control)

increased phosphorus removal could be obtained in reactors by possibly adding a biological suspended growth system. Factors such as composition of wastewater, oxygen supply and active sludge have been recognized to have a positive and negative impact on biological nutrient removal (Rybicki, 1997). The detection of remarkable phosphate and nitrate uptake rate in the earlier batches of this investigation has been reported by earlier workers (Lee et al., 2001). Nitrates in anaerobic zone are an important factor to be taken into consideration, especially in the phosphorus removal activated sludge during domestic wastewater treatment. This could be due to the fact that in the presence of nitrates, the substrates are metabolized through oxidative fermentative pathways (Bitton, 1994). Fig. 4 shows the variation of ammonia removal rate from mixed liquor in the reactors among the different isolates in the different batches. As seen, ammonia removal rate ranged from 0.14 to $0.15 \mathrm{mg}-\mathrm{NH}_{3} / \mathrm{L} / \mathrm{h}$., 0.05 to $0.15 \mathrm{mg}-\mathrm{NH}_{3} / \mathrm{L} / \mathrm{hand} 0.05$ to $0.13 \mathrm{mg}-\mathrm{NH}_{3} / \mathrm{L} / \mathrm{h}$., for Aspidisca, Trachelophyllum and Peranema, respectively. Low ammonia removal rates were observed in batch three when Trachelophyllum was used as inoculum and in batche one when Peranema was used, while in the case of Aspidisca, remarkable removal rates were observed in all the batches. 


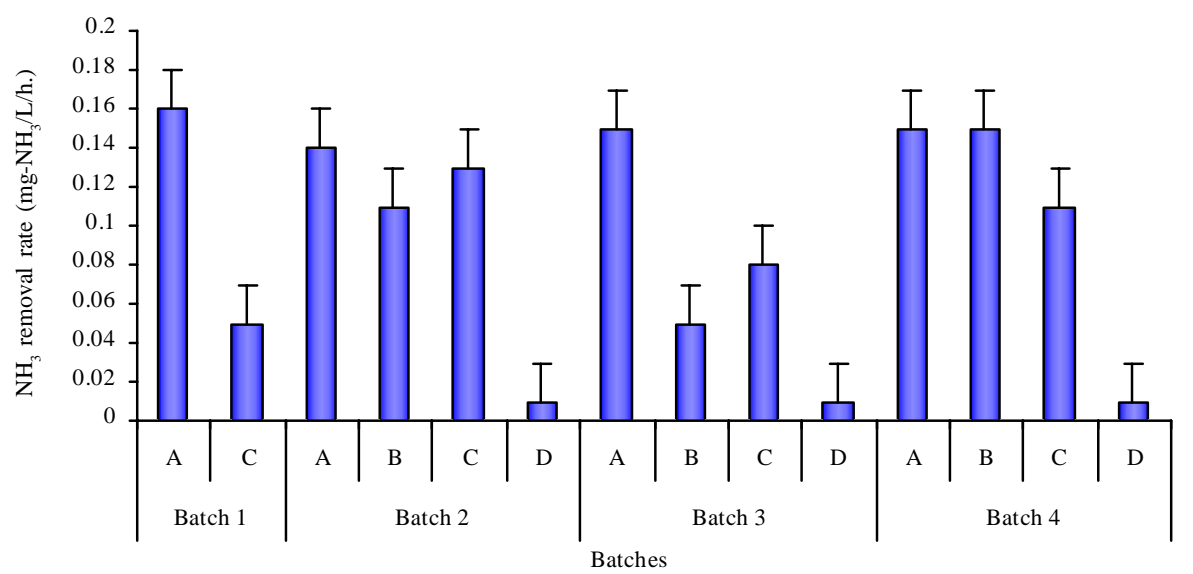

Fig. 4: Variation of ammonia removal rate from mixed liquor inoculated with different isolates from different batches $(\mathrm{A}=$ Aspidisca, $\mathrm{B}=$ Trachelophyllum, $\mathrm{C}=$ Peranema, $\mathrm{D}=$ uninoculated control $)$

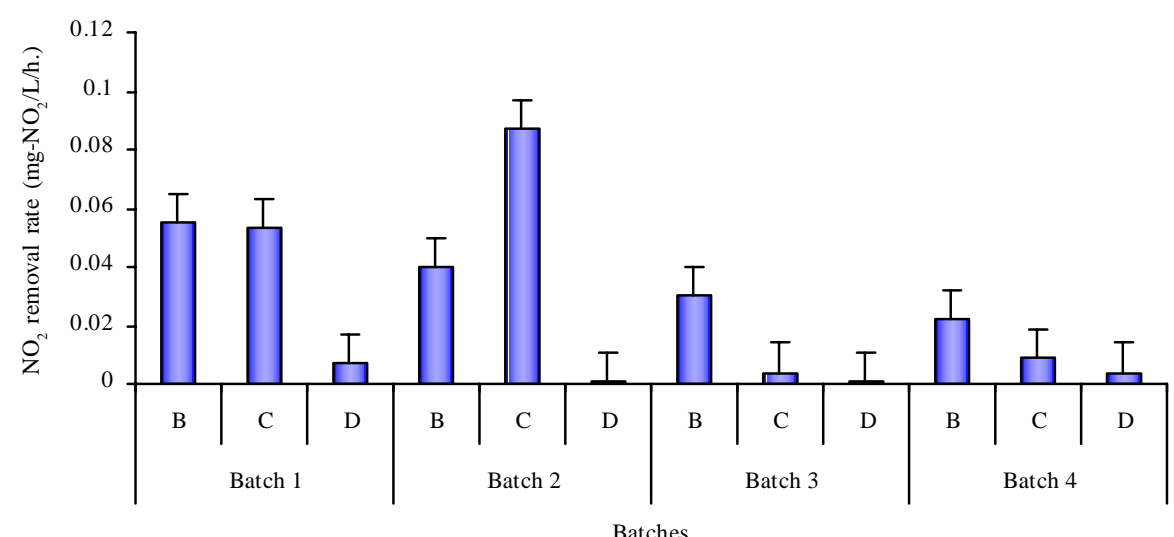

Fig. 5: Variation of nitrite removal rate from mixed liquor inoculated with different isolates from different batches ( $\mathrm{A}=$ Aspidisca, $\mathrm{B}=$ Trachelophyllum, $\mathrm{C}=$ Peranema, $\mathrm{D}=$ uninoculated control $)$

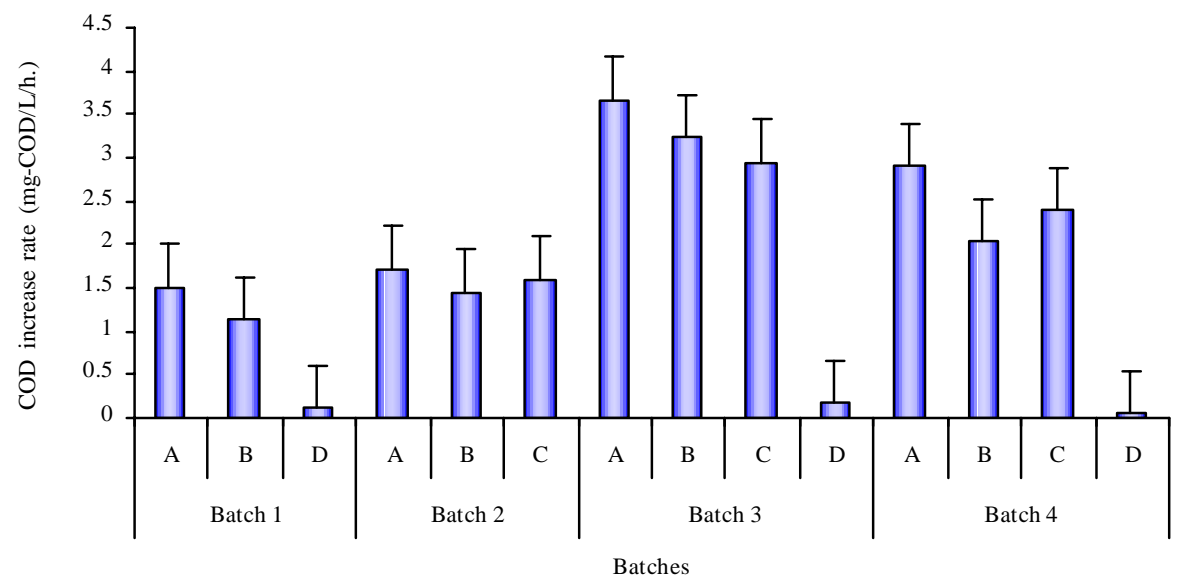

Fig. 6: Variation of COD increase rate in mixed liquor inoculated with different isolates from different batches $(\mathrm{A}=$ Aspidisca, $\mathrm{B}=$ Trachelophyllum, $\mathrm{C}=$ Peranema, $\mathrm{D}=$ uninoculated control $)$ 
As was observed in phosphate and nitrate removal, a relatively high ammonia removal rate was observed in the reactors inoculated with the respective isolates. This was irrespective of the experimental batches. Some studies have reported that with increasing ammonia nitrogen above $1 \mathrm{mg} / \mathrm{L}$ in aerobic zone, concentrations of phosphates also increase in the effluent to $1.5 \mathrm{mg} / \mathrm{L}$ (Matuzevicius and Valentukeciene, 2007).

Although nitrite data for Aspidisca were not reported due to experimental errors, as shown in Fig. 5 nitrite removal rates when Trachelophyllum and Peranema were used as inoculum ranged from 0.021 to $0.055 \mathrm{mg}-\mathrm{NO}_{2} / \mathrm{L} / \mathrm{h}$ पl respectively. As was observed in both nitrate and ammonia removal rates, lowest nitrite removal rates were observed in batch three. This was irrespective of the isolate used.

In this study, nitrite removal rate was observed to be low when compared to phosphate and nitrate removal. This was also irrespective of isolate used and the experimental batch. Reports have shown that in sequencing batch reactors, aerobic phosphate uptake and nitrite removal are negatively correlated (Saito $e t$ al., 2004). Although it is not clear, theoretically, nitrite is reported to play a role as an electron acceptor in the denitrification reaction, during nutrient uptake (Meinhold et al., 1999).

As shown in Fig. 6, highest increase rates of 3.67 $\mathrm{mg}-\mathrm{COD} / \mathrm{L} / \mathrm{K} 3.23 \mathrm{mg}-\mathrm{COD} / \mathrm{L} / \mathrm{h} \mathbb{Z}$-ere observed in batch two when either Aspidisca or Trachelophyllum was

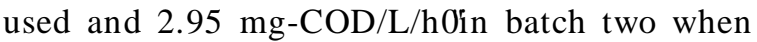
Peranema was used.

Table 1: Variation of concentrations of dissolved oxygen in mixed liquor at the beginning and end of each batch experiment $(\mathrm{mg} / \mathrm{L})$

\begin{tabular}{llll}
\hline Batches & Isolates & Initial $(\mathrm{mg} / \mathrm{L})$ & Final $(\mathrm{mg} / \mathrm{L})$ \\
\hline 1 & A & 3.95 & 0.36 \\
& B & 4.55 & 0.22 \\
& C & 3.30 & 0.21 \\
& D & 3.11 & 2.22 \\
& A & 3.46 & 0.06 \\
& B & 4.18 & 0.20 \\
3 & C & 4.52 & 0.20 \\
& D & 4.17 & 3.52 \\
& A & 3.17 & 0.14 \\
& B & 3.16 & 0.16 \\
& C & 4.00 & 0.14 \\
& D & 4.14 & 2.78 \\
& A & 4.50 & 0.14 \\
& B & 3.83 & 0.14 \\
& C & 4.48 & 0.15 \\
& D & 4.04 & 3.26 \\
\hline
\end{tabular}

Initial: Concentrations at time 0 h., Final: Concentrations after $120 \mathrm{~h}$. (end of each batch), A= Aspidisca, $\mathrm{B}=$ Trachelophyllum, $\mathrm{C}=$ Peranema, Duninoculated control. 1, 2, 3, and 4 represent the different experimental batches

Tabl 2: Variation in mixed liquor $\mathrm{pH}$ at different sampling times during the different batches

\begin{tabular}{llllllll}
\hline Batches & Isolates & $0 \mathrm{~h}$. & $24 \mathrm{~h}$. & $48 \mathrm{~h}$. & $72 \mathrm{~h}$. & $96 \mathrm{~h}$. & $120 \mathrm{~h}$. \\
\hline 1 & A & 9.2 & 8.3 & 8.5 & 8.6 & 8.7 & 8.7 \\
& B & 9.0 & 8.4 & 8.3 & 8.6 & 8.7 & 8.8 \\
& C & 8.8 & 8.1 & 8.6 & 8.9 & 8.8 & 8.8 \\
2 & D & 8.7 & 8.7 & 8.7 & 8.7 & 8.7 & 8.7 \\
& A & 9.1 & 8.7 & 8.2 & 8.6 & 8.7 & 8.9 \\
& B & 8.7 & 8.1 & 8.2 & 8.6 & 8.7 & 8.8 \\
& C & 8.6 & 8.1 & 7.6 & 7.9 & 7.9 & 8.0 \\
3 & D & 8.7 & 8.7 & 8.6 & 8.6 & 8.6 & 8.9 \\
& A & 8.9 & 8.3 & 9.0 & 8.7 & 8.9 & 8.5 \\
& B & 8.8 & 8.0 & 8.3 & 8.7 & 8.5 & 8.7 \\
4 & C & 8.7 & 8.3 & 8.7 & 8.8 & 8.9 & 8.9 \\
& D & 8.7 & 8.8 & 8.7 & 8.7 & 8.8 & 8.5 \\
& A & 8.9 & 8.6 & 9.1 & 9.1 & 9.0 & 8.3 \\
\hline
\end{tabular}

Initial: Concentrations at time 0 h., Final: Concentrations after 120 h. (end of each batch), A= Aspidisca, B= Trachelophyllum, C= Peranema, D- uninoculated control. 1, 2, 3 and 4 represent the different experimental batches 
Chemical oxygen demand removal in mixed liquor was not observed to decrease at the end of each experimental batch, rather there was an increase. The COD increase rates were observed to be high in the later batches. Increase in COD in the presence of sodium acetate as carbon source in mixed liquor, as observed in this study have been reported elsewhere (Akpor et al., 2008). As shown in Table 1, dissolved oxygen concentrations in mixed liquor were observed to decrease to values less than $1 \mathrm{mg} / \mathrm{L}$, after $120 \mathrm{~h}$. reaction time in each batch. This decrease was observed in all the batches and was irrespective of isolates used. Although, this was not observed in this study, some reports have shown that nitrite is only utilized much quickly when nitrate concentration is below $1.0 \mathrm{mg} / \mathrm{L}$. Despite this was not investigated in this study, nitrite is also reported to strongly inhibit phosphate uptake activities in sequencing batch reactors (Kuba et al., 1996).The $\mathrm{pH}$ values of mixed liquor are shown in Table 2. As can be seen from the table, there was a pH decrease after initial $24 \mathrm{~h}$. incubation before there was further progressive increase. This was also irrespective of isolate used and experiment batches (Table 2). This may have been due to the residual dissolved oxygen at the start of each batch, as indicated in the DO values. The accumulation of $\mathrm{CO}_{2}$ from respiratory activity using residual dissolved oxygen is reported to cause a decrease in $\mathrm{pH}$ (Lee et al., 2001). The subsequent increase in $\mathrm{pH}$ after the initial $24 \mathrm{~h}$. may have been due to utilization of residual dissolved oxygen as a result of nutrient uptake, which is reported to consume $\mathrm{H}^{+}$in reactors (Lee et al., 2001; Saito et al., 2004).

\section{CONCLUSION}

This study which was aimed at investigating the nutrient removal rates by protozoan isolates from activated sludge mixed liquor in batch reactors has been able to reveal that:

1.The test protozoan isolates used for this investigation have the ability to remove phosphate and nitrogen compounds form activated sludge mixed liquor that is operated under aerobic conditions.

2. In the presence of the test isolates different nutrients in activated sludge mixed liquor have different removal rate with phosphate removal being the highest.

3. The rate of nutrient removal is dependent on the isolate and the experimental batch for all of the nutrients investigated.
4. None of the isolates used was able to show a decrease in COD concentration of mixed liquor in the reactors, rather there was an increase.

5. There is always an initial drop in $\mathrm{pH}$ of mixed liquor within the first $24 \mathrm{~h}$. while there is a gradual increase against drastic decrease in DO concentrations at the end of each experimental batch.

Overall, the study has been able to show the effect of the test isolates on nutrient removal rates and other physicochemical parameter (COD, DO and $\mathrm{pH}$ ) in activated sludge mixed liquor.

\section{ACKNOWLEDGEMENT}

The authors wish to thank the National Research Foundation (NRF) of South Africa and Tshwane University of Technology for sponsoring this investigation.

\section{REFERENCES}

Akpor, O. B.; Momba, M. N. B.; Okonkwo, J., (2007). Phosphorus and nitrate removal by selected wastewater protozoa isolates. Pakistan J. Biol. Sci., 10 (22), 4008-4014.

Akpor, O. B.; Momba, M. N. B.; Okonkwo, J., (2008). Effect of nutrient nutrient/carbon supplement on biological phosphate and nitrate uptake by protozoa isolates. J. Appl. Sci., 8 (3), 489-495.

APHA, (2001). Standard methods for the examination of water and wastewater. 20 $0^{\text {th. }}$ Ed., American Public Health Association, Washington DC.

Behera, S. K.; Rene, E. R.; Murthy, D. V. S., (2007). Performance of Upflow anoxic bioreactor for wastewater treatment. Int. J. Environ. Sci. Tech., 4 (2), 247-252.

Bitton, G., (1994). Wastewater microbiology. Wiley-Liss, New York.

Doorn, M. R. J.; Towprayoon, S.; Maria, S.; Viera, M.; Irving, W.; Palmer, C.; Pipalti, R.; Wang, C., (2006). Wastewater treatment and discharge. In 2006 IPCC Guidelines for National Greenhouse Gas Inventories 5. WMO, UNEP.

Dola, J. R., (1997). Phosphorus and ammonia excretion by planktonic protists. Mar. Geo., 139 (1), 109-122.

Gerardi, M. H., (2007). The protozoa puzzle. Water and Wastewater News. March Issue.

Ekama, G. A.; Dold, P. L.; Marias, G. R., (1986). Procedures for determining influent COD fraction and the maximum specific growth rate of heterotrophs in activated sludge system. Water Sci. Tech., 18 (6), 91-114.

Johanna, L. P.; Janell, B.; Pamela, R., (1999). The role of flagellated and ciliated protozoa in lagoon and grass filter sewage treatment systems. Water Res., 33 (13), 2971-2977.

Kargi, F.; Uygur, A., (2003). Effects of carbon source on biological nutrient removal in a sequencing batch reactor. Biosci. Tech., 89 (1), 89-93.

Kargi, F.; Uygur, A.; Baskaya, H. S., (2005). Phosphate uptake and release rates with different carbon sources in biological nutrient removal using a SBR. J. Environ. Manage., 76 (1), 71-75.

Kortstee, G. J. J.; Appeldoorn, K. J.; Bonting, C. F. C.; van Niel, E. W. J.; van Veen, H. W., (2000). Recent 
developments in the biochemistry and ecology of enhanced biological phosphorus removal. Biochemistry, 65 (3), 332340 .

Kuba, T.; van Loosdrecht, M. C. M.; Brandse, F. A.; Heijmen, J. J., (1997). Occurrence of denitrifying phosphorus removing bacteria in modified UCT type wastewater treatment plants. Water Res., 31 (4), 777-786.

Kuba, T.; van Loosdrecht, M. C. M.; Heijmen, J. J., (1996). Effect of cyclic oxygen exposure on the activity of denitrifying phosphorus removing bacteria. Water Sci. Tech., 34 (1), 33-40.

Lee, D. S.; Jeon, C. O.; Park, J. M., (2001). Biological nitrogen removal with enhanced phosphate uptake in a sequencing batch reactor using single sludge system. Water Res., 35 (16), 3968-3976.

Matuzevicius, A. B.; Valentukeviciene, M., (2007). Effect of nitrogen on phosphate reduction in biological phosphorus removal from wastewater. Ekologija, 53 (1), 80-88.

Meinhold, J.; Arnold, E.; Isaacs, S., (1999). Effect of nitrite on anoxic phosphate uptake in biological phosphorus removal activated sludge. Water Res., 33 (8), 1871-1883.

Morales, L. M.; Daigger, G. T.; Borberg, J. R., (1991). Capability assessment of biological nutrient removal facilities. Research J. Water Pollut. Cont. F., 63 (6), 900909.

Moosavi, G. H.; Naddafi, K.; Mesdaghinia, A. R.; Nabizadeh, R., (2005). Simultaneous organics and nutrients removal from municipal wastewater in an up-flow anaerobic/aerobic fixed bed reactor. J. Appl. Sci., 5 (3), 503-507.

Okoh, A. I.; Odjadjare, E. E.; Igbinosa, E. O.; Osode, A. N. , (2007). Wastewater treatment plants as a source of microbial pathogens in receiving water sheds. Afr. J. Biotech., 6 (25), 2932-2944.

Ratsak, C. H.; Maarsen, K. A.; Kooijman, S. A. L., (1996). Effects of protozoa on carbon mineralization in activated sludge. Water Res., 30 (1), 1-12.

Rybicki, S., (1997). Advanced wastewater treatment: Phoisphorus removal from wastewater. Joint Polish-Swedish Reports. Report No 1.

Saito, T.; Brdjanovic, D.; van Loosdrecht, M. C. M., (2004). Effect of nitrite on phosphate uptake by phosphate accumulating organisms. Water Res., 38 (17), 3760-3768.

Salvado, H.; Gracia, M. P.; Amigo, J. M., (1995). Capability of ciliated protozoa as indicators of effluent quality in activated sludge plants. Water Res., 29 (4), 1041-1050.

Salvado, H.; Mas, M.; Menendez, S.; Gracia, M. P.; (2001). Effects of shock loads of salt on protozoa communities of activated sludge. Acta Protozool., 40, 177-185.

Sang, L. P.; Jang-Ho, K.; Kwang Baik, K.; Ben K., (1997). Effect of fermented swines wastes on biological nutrient removal in sequencing batch reactors. Water Res., 31 (7), 1807-1812.

Sidat, M.; Kasari, H.C.; Bux, F., (1999). Laboratory-scale investigation of biological Phosphate removal from municipal wastewater. Water SA., 25 (4), 459-462.

Taylor, G. T., (1982). The role of pelagic heterotrophic protozoa in nutrient cycling: a review. Annu. Inst. Oceanogr., 58 (S), 227-241.

Zwart, K. B., Kuikman, P. J., Van Veen, J. A., (1994). Rhizosphere protozoa: their significance in nutrient dynamics. In: Darbyshire, J.F. (Ed.), Soil Protozoa. CAB International. Wallingford, 93-121.

\section{AUTHOR (S) BIOSKETCHES}

Akpor, O. B., B.Sc (Hons.), M.Sc, Ph.D. research student in the Department of Environmental, Water and Earth Sciences, Tshwane Univeristy of Technology, Pretoria, South Africa. Email: akpor2006@gmail.com

Momba, M. N. B., B.Sc (Hons.), M.Sc, Ph.D. and professor in the Department of Environmental, Water and Earth Sciences, Tshwane Univeristy of Technology, Pretoria, South Africa. Email: mombamnb@tut.ac.za.

Okonkwo, J. O., B.Sc (Hons.), M.Sc, Ph.D. and professor in the Department of Environmental, Water and Earth Sciences, Tshwane Univeristy of Technology, Pretoria, South Africa. Email: okonkwoj@tut.ac.za

Coetzee, M. A., B.Sc (Hons.), M.Sc. and lecturer in the Department of Environmental, Water and Earth Sciences, Tshwane Univeristy of Technology, Pretoria, South Africa. Email: coetzeem@tut.ac.za

\section{This article should be referenced as follows:}

Akpor, O. B.; Momba, M. N. B.; Okonkwo, J. O.; Coetzee, M. A., (2008). Nutrient removal from activated sludge mixed liquor by wastewater protozoa in a laboratory scale batch reactor. Int. J. Environ. Sci. Tech., 5 (4), 463-470. 